\title{
A case of temporal triangular alopecia
}

\begin{abstract}
Temporal triangular alopecia (TTA) is a non-cicatricial alopecia characterized by an alopecic patch, usually located in the frontotemporal region, unilateral or bilateral, with an oval or narrow triangular base and no terminal hairs on it. It can manifest at birth or develop in the first years of life. It is a rare condition and its exact etiology remains unknown. The diagnosis is based on its clinical appearance. The differential diagnosis includes alopecia areata, trichotillomania, tractional alopecia and congenital aplasia cutis. Due to its rarity, misdiagnosis and unnecessary treatments can be applied. Clinical and dermoscopic examination is sufficient in the diagnosis of the disease. A 3-year-old boy with a diagnosis of TTA is presented as a case report.

Keywords: Alopecia, triangular, temporal
\end{abstract}

Öz

Temporal triangüler alopesi (TTA), genellikle frontotemporal bölge yerleşimli, unilateral veya bilateral olabilen, oval ya da tabanı dar bir üçgen şeklinde, üzerinde terminal kıllar izlenmeyen alopesik bir yama ile karakterize bir non-skatrisyel alopesi tablosudur. Doğumda ya da hayatın ilk yıllarında ortaya çıkar. Nadir izlenen bir tablodur ve etiyoloji halen belirsizdir. Tanı temelde klinik muayeneye dayanır. Ayıııcı tanıda alopesi areata, trikotillomani, traksiyonel alopesi ve konjenital aplazi kutis yer almaktadır. Nadir izlenmesi nedeniyle yanlış tanı alıp gereksiz tedaviler denenebilmektedir. Hastalığın tanısında klinik ve dermoskopik muayene yeterlidir. Burada TTA tanısı koyduğumuz 3 yaşında bir çocuk olgu sunulmaktadır.

Anahtar Kelimeler: Alopesi, triangüler, temporal

\section{Introduction}

Temporal triangular alopecia (TTA) is a type of non-cicatricial alopecia that manifests at birth or develops in the first years of life'. The disease can usually be diagnosed with a careful dermatological examination, but sometimes it can be confused with other diseases with alopecic patches. Histopathological examination and scalp dermoscopic examination provides useful data in differential diagnosis with diseases such as trichotillomania, traction alopecia, congenital aplasia cutis and alopecia areata².

\section{Case Report}

A 3-year-old boy applied to our clinic with an area of alopecia in the left temporal region. The patient's history revealed that his hair in the scalp was sparse at birth and there was a linear extension area on the left temporal area with no hair on it. The family reported that the lesion had a proportional growth with age. In several previous healthcare centers they had visited, he had been diagnosed with alopecia areata and recommended topical steroid treatments. However, the patient did not benefit from the suggested treatments. In the

Address for Correspondence/Yazışma Adresi: Emre Zekey MD, Selçuk University Faculty of Medicine, Department of Dermatology, Konya, Turkey Phone: +90 5558891889 E-mail: emre.zekey@gmail.com Received/Geliş Tarihi: 05.12.2019 Accepted/Kabul Tarihi: 03.09.2020 ORCID: orcid.org/0000-0001-6237-153 
dermatological examination of the patient, a triangular alopecic patch with a diameter of $5 \times 2 \mathrm{~cm}$, extending from the left frontotemporal region to the malar region, was located above the base. In the part of the patch that intersected with the malar region, there were terminal hairs in an area of approximately $1 \mathrm{~cm}$. Inflammation, erythema and atrophy were not observed in the lesion and its surroundings (Figure $1 \mathrm{a}, \mathrm{b})$. In the dermoscopic examination of the lesion, inanimate yellowwhite vellus-type hairs with differences in diameter (Figure 2a) and mild superficial desquamation (Figure 2b) were observed. Because dermatophyte infection was not considered, a fungal examination was not performed. The patient's teeth and nails were examined as normal. His family did not accept the histopathological examination. The
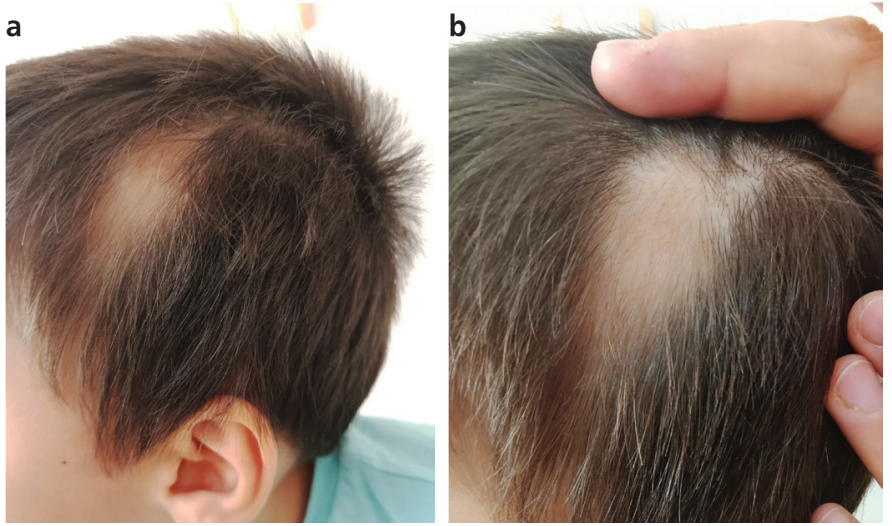

Figure 1a, b. Alopecic patch without inflammation, erythema and atrophy
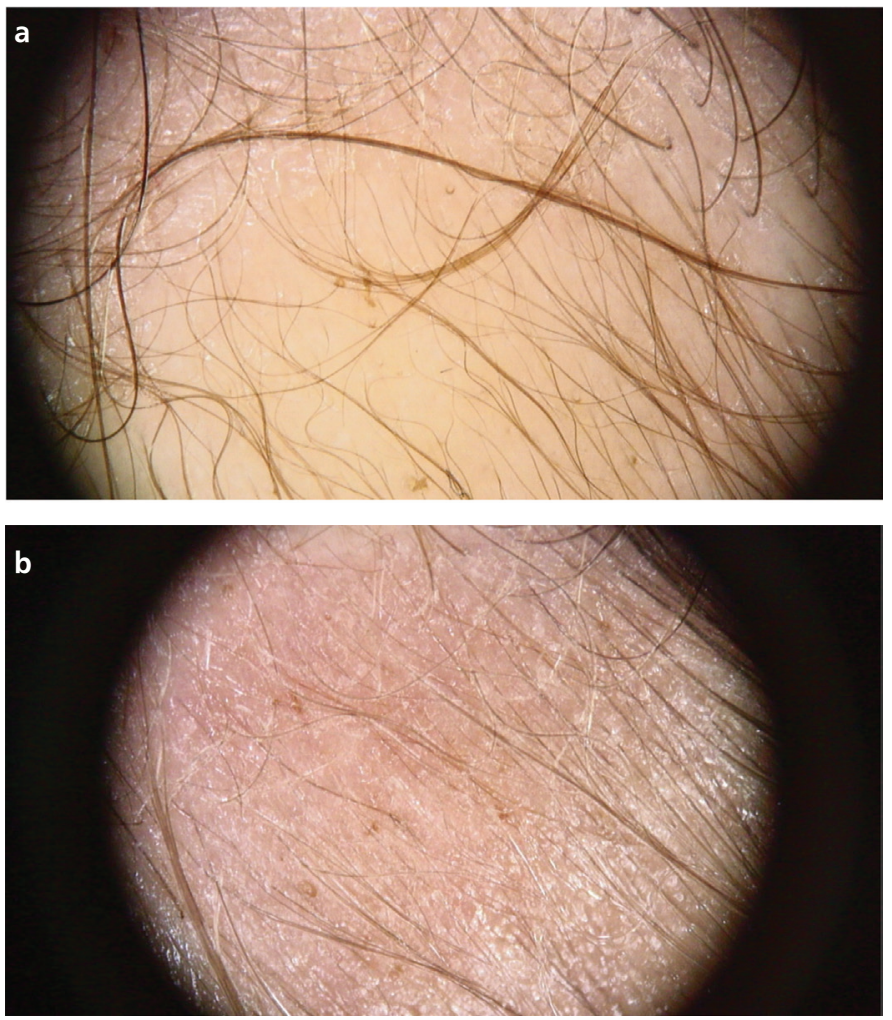

Figure 2a. Inanimate yellow-white vellus type hairs, diameter differences in hair shafts, 2 b. Mild süperficial desquamation on alopecic patch patient was diagnosed with TTA in the light of clinical and dermoscopic findings, and his family was informed about the disease and called for control.

Informed consent was obtained.

\section{Discussion}

TTA is a rare, sharply limited form of non-scarring alopecia, usually located in the frontotemporal region. The condition was first described by Sabouraud in $1905^{3}$. Lesions are $80 \%$ unilateral and $20 \%$ bilateral, and are observed equally in both sexes ${ }^{4}$. In a series, it was reported that $36.5 \%$ of the cases were diagnosed at birth, $55.8 \%$ between the ages of $2-9$, and $3.8 \%$ at adult ages, and the incidence of the disease was $0.11 \%^{2}$. Dermatological examination of the lesions is characterized by an alopecic patch, usually in the form of an oval or narrow base, located in the frontotemporal region. Erythema, inflammation, atrophy, scar and discoloration are not detected in the lesion area. There are no terminal hairs on the lesion, but vellus hairs are observed. Alopecic patch remains stable for life and vellus hair is not expected to turn into terminal hair ${ }^{4}$. Clinical examination is generally sufficient in the diagnosis of the lesion. Dermoscopic and histopathological examination also provide valuable data. In the histopathological examination of the lesion, a normal number of follicles are observed in the superficial dermis, in which the vellus hair is dominant and terminal hair is rarely observed. Inflammation and/or scarring are not observed'. Alopecia areata, trichotillomania, traction alopecia are diseases that should be especially evaluated in the differential diagnosis. However, since the reported number of cases is small, there is no consensus on detailed histopathological data for diagnosis. White hairs, diameter changes, vellus hairs, empty follicles, branching vascular pattern, fine epidermal scales, and broken hairs can be observed in dermoscopy ${ }^{5}$. The presence of normal follicular openings on the lesion supports the diagnosis of TTA. Vellus hairs are observed in the follicles on the lesion, while normal follicular orifices with terminal hairs are observed around the lesion. White hairs, empty follicles, diameter changes, thin vellus hairs, and fine scales were observed in the trichoscopic examination of our case. A biopsy could not be taken and a histopathological examination could not be done because his family did not allow it. The dermoscopic

\begin{tabular}{|c|c|}
\hline $\begin{array}{l}\text { Dermatological } \\
\text { diagnosis }\end{array}$ & Dermoscopic findings \\
\hline $\begin{array}{l}\text { Temporal triangular } \\
\text { alopecia }\end{array}$ & $\begin{array}{l}\text { Short vellus hairs, vellus hair length diversity, } \\
\text { white hairs and dots, and more rarely } \\
\text { honeycomb pigment pattern, arborizing red } \\
\text { lines, epidermal scale }\end{array}$ \\
\hline Alopecia areata & $\begin{array}{l}\text { Yellow dots with short vellus, dystrophic and } \\
\text { tapered hairs, black dots }\end{array}$ \\
\hline Tinea capitis & $\begin{array}{l}\text { Broken hair shafts with desquamation, comma } \\
\text { hairs, corkscrew hairs, blotchy pigmentation, } \\
\text { erythema, desquamation, pustules }\end{array}$ \\
\hline Trichotillomania & $\begin{array}{l}\text { Hair shafts of variable length, longitudinal } \\
\text { splitting of hair shafts, coiled fractured hair8 }\end{array}$ \\
\hline Traction alopecia & Hair loss and weak-thin, lifeless hairs ${ }^{1}$ \\
\hline $\begin{array}{l}\text { Aplasia cutis } \\
\text { congenita }\end{array}$ & $\begin{array}{l}\text { Complete lack of skin appendages, translucent } \\
\text { appearance }^{9}\end{array}$ \\
\hline
\end{tabular}


findings of the diseases diagnosed in the differential are indicated in the table (Table 1).

While peribulbar lymphocytic inflammation is prominent in alopecia areata, inflammation and erythema are not observed in TTA. The lesion does not tend to expand, except for enlargement proportional to the growth of the face as the child grows. In traction alopecia, applying traction or repeated trauma to the hair causes follicular scarring and a decrease in hair density. Another feature is that the hair is broken at the border of the scalp, thus, different lengths of hair are seen in trichotillomania ${ }^{10}$.

In 2011, in a study by Inui et al. ${ }^{1}$ the following diagnostic criteria have been proposed by the clinical and dermoscopic parameters for TTA:

1. Triangular or spear-shaped alopecic patch observed in the frontotemporal region of the scalp.

2. Alopecic patch surrounded by normal terminal hair, with dermoscopically vellus hair and normal follicular openings.

3. Dermoscopically no yellow/black spots, dystrophic hairs and decreased follicular openings.

4. Confirmation of the presence of vellus hairs dermoscopically and clinically and subsequent absence of growth and transformation into terminal hairs during follow-ups.

The etiopathogenesis of TTA is not fully known. Some cases showing familial transition have been reported in the literature ${ }^{11}$. Observation of neurological problems in some familial cases suggests a neuroectodermal differentiation disorder in the embryonic period. In some cases, accompanying mental retardation, heart anomalies, epilepsy, dental disorders support the views on neuroectodermal developmental disorder ${ }^{12,13}$. In our case, no additional systemic anomaly was detected. In the literature, topical steroids and minoxidil were used in some cases for the treatment, but no results could be obtained ${ }^{5}$. Currently, if the area is small, surgical resection looks like the only treatment method; however, if the area is large, scalp graft transplantation appears to be the only treatment. There are case reports in the literature that were successfully treated with scalp graft transplantation ${ }^{14,15}$.

Here, we presented a 3-year-old male patient diagnosed with TTA clinically and dermoscopically, who was misdiagnosed and tried to be treated with topical and intralesional steroids before. We reported this case by thinking that it may help in the early recognition of the lesion and prevention of unnecessary treatments.

\section{Ethics}

Informed Consent: It was obtained.

Peer-review: Externally peer-reviewed.

\section{Authorship Contributions}

Surgical and Medical Practices: E.Z., G.S.K., Concept: E.Z., G.S.K., Design: E.Z., G.S.K., Data Collection or Processing: E.Z., G.S.K., Analysis or Interpretation: E.Z., G.S.K., Literature Search: E.Z., G.S.K., Writing: E.Z., G.S.K.

Conflict of Interest: No conflict of interest was declared by the authors.

Financial Disclosure: The authors declared that this study has received no financial support.

\section{References}

1. Inui $\mathrm{S}$, Nakajima $\mathrm{T}$, Itami $\mathrm{S}$ : Temporal triangular alopecia: trichoscopic diagnosis. J Dermatol 2012;39:572-4.

2. Yamazaki M, Irisawa $\mathrm{R}$, Tsuboi R: Temporal triangular alopecia and a review of 52 past cases. J Dermatol 2010;37:360-2.

3. Bargman $\mathrm{H}$ : Congenital temporal triangular alopecia. Can Med Assoc J 1984;131:1253.

4. Trakimas C, Sperling LC, Skelton HG, Smith KJ, Buker JL: Clinical and histologic findings in temporal triangular alopecia. J Am Acad Dermatol 1994;31:2059

5. Inui S: Trichoscopy for common hair loss diseases: algorithmic method for diagnosis. J Dermatol 2011;38:71-5.

6. Karadağ Köse Ö, Güleç A: Temporal triangular alopecia: significance of trichoscopy in differential diagnosis. J Eur Acad Dermatol Venereol 2015:29:1621-5

7. Jain N, Doshi B, Khopkar U: Trichoscopy in alopecias: Diagnosis simplified. Int J Trichology 2013;5:170.

8. Tosti $A$, Miteva $M$, Torres $F$, Vincenzi $C$, Romanelli $P$ : Hair casts are a dermoscopic clue for the diagnosis of traction alopecia. $\mathrm{Br} J$ Dermatol 2010;163:1353-5

9. Neri I, Savoia F, Giacomini F, Raone B, Aprile S, Patrizi A: Usefulness of dermatoscopy for the early diagnosis of sebaceous nevus and differentiation from aplasia cutis congenita. Clin Exp Dermatol 2009;4:e50-2.

10. Yaşar ŞP, Tülin A, Göktay F, Serdar ZA, Barutçugil B, Güneş P: Trichoscopy in alopecias. Turkiye Klinikleri J Dermatol 2008;18:106-9.

11. Patrizi $A$, Morrone $P$, Fiorentini $C$, Bianchi $T$ : An additional familial case of temporal triangular alopecia. Pediatr Dermatol 2001;18:261-4.

12. Ruggieri M, Rizzo R, Pavone P, Baieli S, Sorge G, Happle R: Temporal triangular alopecia in association with mental retardation and epilepsy in a mother and daughter. Arch Dermatol 2000;136:426-7.

13. Park S-W, Choi Y-D, Wang H-Y: Congenital triangular alopecia in association with congenital heart diseases, bone and teeth abnormalities, multiple lentigines and café-au-lait patches. Int J Dermatol 2004;43:366-7.

14. Chung J, Sim JH, Gye J, et al: Successful hair transplantation for treatment of acquired temporal triangular alopecia. Dermatol Surg 2012;38:404-6.

15. Wu W-Y, Otberg N, Kang H, Zanet L, Shapiro J: Successful treatment of temporal triangular alopecia by hair restoration surgery using follicular unit transplantation. Dermatol Surg 2009;35:1307-10. 